UDC 340.12

DOI https:// doi.org/10.32841/ILA.2020.23.12

\author{
HORIELOVA V. YU., \\ Candidate of Legal Sciences, Associate Professor, \\ Associate Professor at the Department of State Legal Sciences \\ University of Economy and Right "KROK"
}

\title{
MORAL ASPECTS OF PROTECTION OF PERSONAL DATA OF INDIVIDUALS IN INTERNATIONAL DOCUMENTS AND JUDGMENTS OF THE EUROPEAN COURT OF HUMAN RIGHTS
}

Summary. The article examines the moral aspects of personal data protection of individuals in international legal acts and decisions of the European Court of Human Rights, because personal data protection is a plane of the moral side of human existence, which is fundamental for the realization of this person's right to respect for private life. and family life. According to the provisions of national and international law, it is established that the category of "personal data" coincides in its understanding with the categories of "confidential information" and "personal information". The article analyzes the international legal acts on the protection of personal data of individuals. A special provision is the provision according to which personal data indicating racial, political, religious or other beliefs, as well as data related to health. I or a person's sexual life and those data relating to the criminal conviction of a person may not be subjected to automated processing if domestic law does not provide adequate guarantees for the protection of personal data. Also, the European Community generally advises States to refrain from automated processing of personal data if appropriate data safeguards are not taken when storing such data in files to prevent accidental or unauthorized destruction or accidental loss of data and to prevent unauthorized access, alteration or alteration. dissemination of such information, and if there are no appropriate sanctions in the state in cases of violations of the provisions on personal data protection. The basic moral and legal principles and features on which the European Court of Human Rights is based in its decisions are revealed. Thus, the European Court in its decisions has established that a person may suffer non-pecuniary damage in the following cases: reasonable and unreasonable duration of data storage; violation of a person's right to personal development, as well as the right to establish and develop relationships with other people and with the outside world; in cases of systematic or permanent accounting of personal information, even in cases where such data may be contained in publicly available or other sources; in cases of collecting information about a person using a GPS device attached to his car and data about his location and movement in the public sphere. In view of the above.

Key words: personal data, identity, human rights protection, morality.

Formulation of the problem. The protection of personal data is a kind of plane of the moral side of human existence, because the main moral levers here are the inner, personal side of life of an individual, which is fundamental to the 
realization of this person's guaranteed right to respect for private and family life. In the rulings of the European Court of Human Rights and Fundamental Freedoms, it can be seen that a person is often inflicted with moral damage, which for most people is a much more painful moment than property. However, there are gaps between the proclaimed law and life practice.

Analysis of recent research and publications. Recent studies of moral approaches to the protection of personal data include the work of Wanbil W. Lee, S. Cheung, W. Zankl. This article analyzes Ukrainian law, case law of the European Court of Human Rights, as well as legal documents of the European Union.

Part of the general problem has not been solved previously. Research conducted in the field of personal data protection concerned the terminology, European law and basic principles of personal data protection in European law on personal data protection, and therefore the issue of morality in this area was not paid and it needs its scientific and theoretical study.

Formulating the goals of the article. The purpose of this article is consideration of the moral aspects of the essence of personal data protection of an individual and the approaches of the European Court of Human Rights in understanding this issue; analysis of European legal acts and standards in the field of personal data protection and explore the systems of basic moral and legal principles and features on which they are formed.

Presentation of the main research material. According to Article 11 of the Law of Ukraine "On Information", personal data is information or a set of information about an individual who is identified or can be specifically identified. Further, the category "personal data" coincides in its understanding with the category of "confidential information" about the individual to whom his data belongs: address, date and place of birth, nationality, education, marital status, religious beliefs and health status. Such information may not be collected, stored, used and disseminated by law without the consent of the person, except as provided by law, and only in the interests of national security, economic prosperity and the protection of human rights. Article 21 of the Law of Ukraine "On Information" stipulates that information about an individual is confidential, as well as information access to which is restricted by a natural or legal person, except for subjects of power. Confidential information may be disseminated at the request (consent) of the person concerned in the manner prescribed by him in accordance with the conditions provided by him, as well as in other cases specified by law [1]. In addition, the decision of the Constitutional Court of Ukraine in October 1997 clarified that confidential information, in addition to the above, also includes information about property and other personal data [2]. From the content of these documents, it can be concluded that the central category of personal data protection is the personal life of a person, in which "no one can interfere" except as provided by law, and only in the interests of national security, economic prosperity and human rights (Article 32 of the Constitution of Ukraine) [3].

The category "personal information" also coincides with the content and meaning of the category "personal data of a person", which means any information relating to a specific person or a person who may be specifically identified 
(Article 2 of the Council of Europe Convention for the Protection of Personal Data). persons in connection with the automated processing of "personal data" [4]. However, a more extended concept of the category "personal data" of a person is contained in Article 2 of the Directive of the European Parliament and the Council "On the protection of individuals with regard to the processing of personal data and the free movement of such data". information by which it can be established directly or indirectly, in particular using an identification code or one or more factors inherent in physical, physiological, mental, economic, cultural or social aspects of her personality [5]. The establishment of Regulation (EC) No 2016/679 of the European Parliament and of the Council of 27 April 2016 on the protection of individuals about the processing of personal data and the free movement of such data has led to the repeal of the Directive. Thus, Article 21 of the Regulation defines a person's right to object to the processing of personal data: "the data subject must have the right to object, on grounds relating to his or her particular situation, at any time, against the processing of his or her data. Data". Following Article 25 of the Regulations, in cases of probability of violations of the rights and freedoms of individuals that may cause data processing, it is necessary to take the necessary technical measures, such as the use of pseudonyms, designed to effectively implement the principles of data protection, as well as data minimization and ensuring that "by default, only those personal data are processed that are necessary for each specific purpose of processing". Also, the provisions of the Regulations regarding the right of a person to correct his inaccurate personal data are highly moral (Article 16); the right to erase one's personal data (Article 17); the right to restrict data processing (Article 18), etc. [6].

In the era of information society and almost without the border world of the Internet, the issue of protection of personal data (information about a person, confidential information) as a respect for his rights and fundamental freedoms, including his right to privacy, in connection with automated processing of personal data. data. In this regard, in Art. 5 of the Convention for the Protection of Individuals about Automatic Processing of Personal Data states that "personal data which are subject to automated processing must: be received and processed in good faith and lawfully; be kept for specified and lawful purposes and not used in a manner incompatible with those purposes, be adequate, appropriate and not excessive to the purposes for which they are stored; be accurate and, if necessary, updated". The following provision is also important: personal data indicating racial, political, religious or other beliefs, as well as data relating to a person's health or sexual life and personal data, and relating to a criminal conviction may not be subject to criminal investigation. automated processing, if domestic law does not provide appropriate guarantees (Article 6) [4]. Thus, the European Community generally advises States to refrain from automated processing of personal data if appropriate data safeguards are not taken when storing such data in files to prevent accidental or unauthorized destruction or accidental loss of data, as well as to prevent unauthorized access, alteration or alteration. such information (following Article 10) [4]. 
One of the moral aspects of the protection of personal data is the right to freedom of expression, which includes the freedom to transmit information, which is also restricted if necessary in a democratic society or in the interests of national security, territorial integrity or public security, to prevent riots or crimes. and to protect health or morals, to protect the reputation or rights of others, to prevent the disclosure of confidential information or to maintain the authority and impartiality of the court (by Article 10) [7]. Thus, due to the increasing use and processing of personal data in the member states of the European Community in various spheres of social and economic activity, any processing of personal data must take place in strict accordance with the law. According to the case-law of the European Court of Human Rights, the expression "following the law" had a basis in national law and was conditioned by the quality of the relevant law in the sense that the law must be available to the person concerned, who must be able to foresee its consequences. (cases "Shimovolos v. Russia", "Kruslen v. France"). According to foreign researchers, personal data as private property, as well as categories such as "trust" and "security" are closely interrelated, as are law and morality. Provisions for maintaining the confidentiality and security of personal data must be based on trust. In this regard, researchers give accurate life examples: "you can be allowed to enter the zone of inaccessibility only to those you trust and no one will feel safe if you do not trust the security guarantor" [8]. Thus, confidentiality in the processing of personal data will always be ensured if the law will not only protect but also punish. In this case, only morality can provide a context for such a law, for example: the law in some cases allows interference with the personal data of a person, but it is morality that contributes to the justice of such an intervention. If the result of an illegal and arbitrary breach of confidentiality in the processing of personal data is a loss of trust in public authorities, such a state demonstrates disrespect for law and morality and risks losing the rule of law.

According to the moral considerations of the General Data Protection Regulation (GDPR) [9], personal data: 1) must be processed in a lawful, fair and transparent manner to the data subject; 2) must be collected for specific, explicit and legitimate purposes and not further processed in a way incompatible with those purposes; 3 ) must be stored and archived only in the public interest, for scientific or historical research or statistical purposes; 4) all reasonable steps must be taken to ensure that personal data that are inaccurate, taking into account the purposes for which they are processed, are deleted or corrected without delay; 5) must be stored in a format that allows the identification of data subjects no longer than is necessary for the purposes for which personal data are processed.

Ethical in case of leakage of personal data will be an immediate (no later than 72 hours after learning) notification of a violation of personal data to the supervisory authority (Article 33) [9]. Such notification shall include: the nature of the personal data breach, a description of the likely consequences and a description of the measures taken to eliminate the leakage of personal data, including, if necessary, measures to mitigate possible adverse effects of such leak- 
age (Article 33) [9]. If the violation of personal data may lead to a high risk to the rights and freedoms of individuals, the controller must without undue delay report the violation of personal data to the data subject (Article 34) [9].

Aware of its spiritual and moral heritage, the European Union emphasizes that its activities are based on indivisible and common values (human dignity, freedom, equality and solidarity). In proclaiming the Charter of Fundamental Rights of the European Union (2000 / C 364/01), the European Community also emphasizes, among other fundamental rights, the right to the protection of personal data, emphasizing that "such data must be processed exclusively for specific purposes and with the consent of the data subject" (P. 8) [10]. In this regard, the European Court of Human Rights has repeatedly stated the need to take measures to preserve the inviolability and confidentiality of information and the procedure for its destruction, which provides sufficient guarantees against abuse and arbitrariness of the authorities (Kruslin v. France, Rotaru v. Romania, "Weber and Saravia".

The protection of personal data in the decisions of the European Court of Human Rights is examined in the part of the right to respect for private life, which is enshrined in Art. 8 of the Convention for the Protection of Human Rights and Fundamental Freedoms. The European Court of Justice has ruled that the protection of personal data is fundamental to the realization of a person's guaranteed right to respect for private and family life, as the unlawful processing of confidential information can seriously affect a person's social, spiritual, moral and employment status. about the person may be the subject of abuse and possible persecution. Thus, the Court considers that it is morally reasonable and possible:

- transfer of personal data in case of "acute social need" (cases of "Avilkin and others v. Russia", "Z. v. Finland”, "Helili v. Switzerland”);

- transfer of personal data if it is "necessary in a democratic society" (Surikov v. Ukraine, Z. v. Finland, Connors v. the United Kingdom).

The European Court of Justice has also ruled that a person may suffer non-pecuniary damage in the following cases: 1) excessive and unreasonable retention of data (Brune v. France, Kruslin v. France, S. and Marper v. The United Kingdom, "Kinnunen v. Finland"); 2) violation of a person's right to personal development, as well as the right to establish and develop relations with other people and with the outside world (the cases of Burghartz v. Switzerland, Friedl v. Austria, Sciacca v. Italy, etc.); 3) in cases of systematic or permanent accounting of personal information, even in cases where such data may be contained in publicly available or other sources (the case of "PG and JH v. The United Kingdom"); 4) in cases of collecting information about a person using a GPS device attached to his car.

Guidelines for protection against unauthorized collection, processing, storage and dissemination of personal data in Ukraine are currently enshrined in a special law "On Personal Data Protection" [11], as well as the relevant provisions of the Law of Ukraine "On Access to Public Information" [12]. However, the European Court drew attention to the lack of legislation in Ukraine on the collection, storage, use and dissemination of information about persons (Zaichenko 
v. Ukraine), which in our opinion needs some improvement to bring existing national legislation into line with European Community requirements. on the protection of personal data of a person and his moral condition associated with the use of his data.

Conclusions. Based on the above, we can conclude that there is an urgent need to rethink the category of "personal data of an individual" to improve the current legislation of Ukraine and bring it into line with European law. In particular, it is necessary to include a relevant list of personal data in the Law of Ukraine "On Personal Data Protection", the collection of which would be prosecuted by law.

\section{References:}

1. Law of Ukraine "On Information". URL: https://zakon.rada.gov.ua/laws/show/ 2657-12\#Text.

2. Judgment of the Constitutional Court of Ukraine in the case concerning the official interpretation of Articles 3, 23, 31, 47, 48 of the Law of Ukraine "On Information" and Article 12 of the Law of Ukraine "On the Prosecutor's Office" (case of KG Ustymenko) of 30 October 1997. URL: https://zakon.rada.gov.ua/laws/show/ v005p710-97\#Text.

3. The Constitution of Ukraine. URL: https://zakon.rada.gov.ua/laws/show/254\% D0\%BA/96-\%D0\%B2\%D1\%80\#Text.

4. Council of Europe Convention № 108 "On the Protection of Individuals with regard to Automatic Processing of Personal Data". URL: https://zakon.rada.gov.ua/laws/ show/994_326\#Text.

5. Directive 95/46 / EC of the European Parliament and of the Council "On the protection of individuals with regard to the processing of personal data and on the free movement of such data". URL: https://zakon.rada.gov.ua/laws/show 994_242\#Text.

6. REGULATION OF THE EUROPEAN PARLIAMENT AND OF THE COUNCIL (EU) 2016/679 of 27 April 2016 on the protection of individuals with regard to the processing of personal data and on the free movement of such data and repealing Directive 95/46 / EC (General Regulation on data protection). URL: https://zakon.rada.gov.ua/laws/show/984_008-16\#Text.

7. European Convention for the Protection of Human Rights and Fundamental Freedoms. URL: https: //zakon.rada.gov.ua/laws/show/995_004\#Text.

8. Wanbil W. Lee. An Ethical Approach to Data Privacy Protection, 2016. URL: https://www.isaca.org/resources/isaca-journal/issues/2016/volume-6/anethical-approach-to-data-privacy-protection.

9. General Data Protection Regulation, GDPR. URL: https://gdpr-info.eu/.

10. Charter of Fundamental Rights of the European Union (2000 / C 364/01). URL: https://zakon.rada.gov.ua/laws/show/994_524\#Text.

11. Law of Ukraine "On Personal Data Protection". URL: https://zakon.rada.gov.ua/ laws/show/2297-17\#Text.

12. Law of Ukraine "On Access to Public Information". URL: https://zakon.rada.gov.ua/ laws/show/2939-17\#Text. 
Горєлова В. Ю. Моральні аспекти захисту персональних даних фізичних осіб в міжнародних документах та рішеннях Європейського суду з прав людини

Анотація. У статті досліджуються моральні аспекти захисту персональних даних фізичних осіб у міжнародних правових актах і рішеннях $Є$ вропейського судуз прав людини, адже захист персональних даних - це площина саме морального боку людського буття, що має фундаментальне значення для реалізації цією особою гарантованого їй права на повагу до приватного й сімейного життя. За положеннями національного й міжнародного законодавства встановлено, що категорія «персональні дані» збігається у своєму розумінні 3 категоріями «конфіденційна інформація» та «інформація про особу». У статті проводиться аналіз міжнародний правових актів щодо захисту персональних даних фізичних осіб. Особливим вбачається положення, відповідно до якого персональні дані, що свідчать про расову приналежність, політичні, релігійні чи інші переконання, а також дані, що стосуються здоров'я або статевого життя особи, засудження особи в кримінальному порядку, не можуть піддаватися автоматизованій обробці, якщо внутрішнє законодавство не забезпечує відповідних гарантій захисту персональних даних. До того ж Європейське товариство взагалі радить утримуватися державам від автоматизованої обробки персональних даних людини, якщо в разі зберігання у файлах таких даних не вживають відповідних заходів безпеки, спрямованих на запобігання випадковому чи несанкціонованому знищенню або випадковій утраті даних, а також на запобігання несанкціонованому доступу, зміні або поширенню такої інформації, та якщо в державі відсутні відповідні санкції у випадках порушень положень щодо захисту персональних даних. Виявлені базові морально-правові принципи й особливості, на яких грунтується Європейський суд із прав людини у своїх рішеннях. Так, Європейський суд у своїх рішеннях встановив, що особі може бути завдано моральних втрат у випадках: надмірної та необгрунтованої тривалості зберігання даних; порушення права особи на особистісний розвиток, а також на право налагоджувати й розвивати стосунки з іншими людьми й із зовнішнім світом; систематичного або постійного обліку інформації про особу навіть у випадках, коли такі дані можуть міститися в загальнодоступних або інших джерелах; збору інформації про особу за допомогою пристрою GPS, прикріпленого до іï автомобіля, та даних про іiї місцеперебування та переміщення в публічній сфері. 3 огляду на зазначене в статті, пропонується внести до національного законодавства відповідний перелік інформації (персональних даних), збирання якої 6 переслідувалося законом.

Ключові слова: персональні дані, особа, захист прав людини, мораль. 